\title{
Battery Problem: Low Impedence
}

National Cancer Institute

\section{Source}

National Cancer Institute. Battery Problem: Low Impedence. NCI Thesaurus. Code C64335.

Problem related to decreased battery internal impedance. 